\title{
Korean Wave as Tool for Korea’s New Cultural Diplomacy
}

\author{
Gunjoo Jang ${ }^{1}$, Won K. Paik ${ }^{2,3}$ \\ ${ }^{1}$ Department of Curriculum, Korea Institute for Curriculum and Evaluation, Seoul, Korea (South) \\ ${ }^{2}$ Department of Political Science and Diplomacy, Hankuk University of Foreign Studies, Seoul, Korea (South) \\ ${ }^{3}$ Department of Political Science, Central Michigan University, Mt. Pleasant, Michigan, USA \\ Email: kjchang@kice.re.kr, paik1wk@hufs.ac.kr
}

Received May 20 $0^{\text {th }}$, 2012; revised June $24^{\text {th }}$, 2012; accepted July $8^{\text {th }}$, 2012

\begin{abstract}
In recent years, there has been an influx of Korean popular culture throughout the world, including East Asia, Southeast Asia, Europe, and the Americas. Korean popular culture, also known as the "Korean Wave" (Hallyu in Korean) ranges from television dramas, movies, popular music (K-pop), dance (B-boys), video game, food, fashion, tourism, and language (Hangul). The main focus of this paper is to examine the essence of the Korean Wave and its impact on the world. In particular, this paper aims to explore the relationships between the spread of the Korean Wave and political and social changes in a global perspective. That is, does the Korean Wave affect the political position and diplomatic leverage of Korea in any meaningful way? Toward this objective, this paper first examines the relevant literature of international relations for policy and culture change, especially with regards to globalization, interdependence, soft power and world value change. Then, recent developments of the Korean Wave are reviewed and critically analyzed in order to ascertain political and policy implications for Korean diplomatic and practical directives. Finally, we will draw an interpretive conclusion and recommendations toward the plausibility of the Korean Wave as a policy tool for Korea's cultural diplomacy.
\end{abstract}

Keywords: Korean Wave; Cultural Diplomacy; Complex Interdependence; Globalization; Soft Power; World Value Change

\section{Introduction}

In recent years, there has been an influx of Korean popular culture throughout the world. ${ }^{1}$ It began from a small part of East Asia and has been spread out to the world, including East Asia, Southeast Asia, Europe, and the Americas. Korean popular culture products, also known as the "Korean Wave" (Hallyu in Korean) ranges from television dramas, movies, popular music (K-pop), dance (B-boys), and to a lesser extent video games, food, fashion, tourism, and language (Hangul). The term Korean Wave was coined by the Chinese press (Hanliu in Chinese) a little more than a decade ago to refer to the popularity of Korean pop culture in China. The popular idol group H.O.T.'s concert held in Beijing gave the chance for Chinese press to coin the word: "The boom started with the export of Korean television dramas (mini-series) to China in the late 1990s. Since then, South Korea has emerged as a new center for the production of transnational pop culture, exporting a range of cultural products to neighboring Asian countries. More recently, Korean pop culture has begun spreading from its comfort zone in Asia to more global audiences in the Middle East, Africa, Europe, and the Americas.” (The Korean Wave, 2011: p. 11).

At the same time, the Korean government has tried to take the advantage of the Korean Wave as a policy tool to improve its cultural and public diplomacy. ${ }^{2}$ Under Lee Presidency, the Korean government has placed "complex diplomacy" and "value diplomacy" the main policy objectives to improve cultural and public diplomacy along with enhancing national image and national brand. In particular, the Ministry of Foreign Affairs and Trade and the Presidential Council on Nation Branding have been seeking to take advantage of the popularity of the Korean Wave to promote Korean national interest and to enhance Korean images in the world. ${ }^{3}$

In these backdrops, the main focus of this paper is to examine the essence of the Korean Wave and its impact on the world. In particular, this paper aims to explore the relationships between the spread of the Korean Wave and political and social changes in a global perspective. That is, does the Korean Wave affect the political position and diplomatic leverage of Korea in any meaningful way? Toward this objective, this paper first examines the relevant literature of international relations for policy and culture change, especially with regards to globalization, complex interdependence, soft power and world value change. Then, recent developments of the Korean Wave are reviewed and critically analyzed in order to ascertain political and policy implications for Korean diplomatic and practical directives. Finally, we will draw an interpretive conclusion and recommendations toward the plausibility of the Korean Wave as a policy tool for Korea's cultural diplomacy.

\section{Theoretical Discussion}

World is Flat? One of the controversial debates in recent

\footnotetext{
${ }^{1}$ Hereafter "Korean" refers South Korean.

${ }^{2}$ Cultural diplomacy is defined as "the practice of using cultural resources to facilitate the achievement of foreign policy objectives, and international cultural relations as the practice of using diplomatic resources to facilitate the achievement of cultural policy objective (Kim \& Ni, 2011: p. 141).

${ }^{3}$ Korea became the first country to establish a presidential council to coordinate efforts to improve national image and national brand. The Council hosted The Korea Nation Branding Convention 2011 under the slogan "Hallyu, into the Future with World," in Seoul, Korea, August 25-28, 2011. At the same time, the Ministry of Foreign Affairs and Trade has published the first 'Cultural Diplomacy Manual' in 2010.
} 
years has been the nature of globalization and the subsequent structural and systemic attributes of global transformation. Feiock et al. (2008) examines the debate between two contending views regarding globalization. On the one hand, Friedman (2005) claims the "world is flat" and that globalization in the information age has diminished the importance of location as a competitive edge in fostering economic growth. On the other hand, Florida (2005) argues that the world is spiky and that while globalization has exposed many regions to heightened competition, the world is far from flat. It is still quite mountainous or "spiky," because it is full of clusters where location matters, most notably in cities. Feiock et al. (2008: p. 15) concludes that globalization has produced a world that is neither flat nor spiky: "More apt is a metaphor portraying the economic world as, if you will, more clustered and rough (regionally focused) than flat (globally focused) or spiky (locally focused). Simply put, economic development success gravitates toward interconnected regional entities whose competitive advantages lies in their collaboration. However, we need to note that in the globalized world and emergence of network society, the clustered world is closely interconnected to one another regardless of the distance or location.

Complex Interdpendenc. According to Keohane and Nye (2001: p. 7), dependence means a state of being determined or significantly affected by external forces. Interdependence, which most simply defined means mutual dependence, refers to situations characterized by reciprocal effects among countries or among actors within different countries. In the era of interdependence, what is the connection between the Korean Wave and international actors and institutions? By importing the concept of interdependence from international relations toward the Korean Wave, we hope to identify factors that promote cultural globalization and the changes in power structures in the globalizing world. Such an approach emphasizes the importance of cross-national comparative analyses. In this vein, there is a need to examine an interaction between the spread of the Korean Wave and its plausible impacts on other countries.

As globalization became a buzzword in the 1990s, Keohane and Nye (2001: pp. 228-233) argued that globalism involves spatially extensive networks of interdependence, and is defined as "a state of world involving networks of interdependence at multicontinental distances, linked through flows and influences of capital and goods, information and ideas, people and force, as well as environmentally and biologically relevant substances." Since interdependence refers to situations characterized by reciprocal effects among countries or among actors in different countries, globalism is a type of interdependence with two special characteristics: 1) Globalism refers to networks of connections (multiple relationships), not simply to single linkages; 2) Globalization is not a process that involves the retreat of the state because the state remains a strategic contested terrain, control of which is pivotal to world order. It is a process involving increased cross-border socioeconomic activity, making it enormously difficult to distinguish between global and national and in fact, the global becomes the national and vice-versa. ${ }^{4}$ This renders the excessively vertical view of the

\footnotetext{
${ }^{4}$ Globalization usually refers to a multi-dimensional process whereby markets, firms, productions, and national financial systems are integrated on a global scale. At the same time, globalization in other areas of life, such as communication, might have a ramification in non-economic areas too, as in cultural affairs-and these can have subsequent political consequence (Brawley, 2003: pp. 12-17).
}

world found in mainstream international relations theory in the shape of traditional levels of analysis and dichotomous external-internal approaches increasingly meaningless (Baker, 2000: pp. 366-367). For a network of relationships to be considered global it must include multicontinental distances, not simply regional networks. Accordingly, interdependence and globalism are both multidimensional phenomena with distinct types of flows and perceptual connections that occur in spatially extensive networks in economic, military, environmental, social and cultural dimensions (Keohane \& Nye, 2001).

Complex interdependence got its driving force with the advent of network society. By network society, we refer to the social structure that results from the interaction between social organization, social change, and a technological paradigm constituted around digital information and communication technologies (Castells, 2004: preface p. 17). The network society has been presenting certain common feature which is determined by the cultural and institutional environments in which it evolves. Simply put, the network has no center, just nodes. And these nodes are interconnected whose importance does not stem from its specific features but from its ability to contribute to the network's goals (Castells, 2004: p. 3). All nodes of a network are necessary for the network's performance. This fits the interpretation of complex interdependence, and shows the possible interconnection between a regionally confined cultural phenomenon and its impact on the world.

Soft Power and Cultural Diplomacy. The end of the Cold War, increasing complex interdependence among societies, and the advent of information technology have prompted an increase attention for public diplomacy in foreign policy making processes. ${ }^{5}$ There has been a gradual and yet steady transformation in methods, contents, and scopes of foreign policy making apparatus. Along this vein, there is an increasing support for Nye's argument regarding "soft power." Nye (2004) defines soft power as the ability to get what you want through attraction rather than coercion or payments. It arises from the attractiveness of a country's culture, political ideals, and policies. When our policies are seen as legitimate in the eyes of others, our soft power is enhanced. He also noted that soft power "could be developed through relations with allies, economic assistance, and cultural exchanges.” As opposed to "hard power" or use of coercion, Nye argues that this would result in "a more favorable public opinion and credibility abroad.” Accordingly, we expect the diplomacy in the $21^{\text {st }}$ century would move toward actively taking advantage of the influence of public opinion which results in strengthening the public diplomacy. The main trend of today's diplomacy is to pursue national interests by influencing the public opinion of other states. Complex interdependence has caused the two fold phenomenon of synchronization and differentiation of domestic politics and international relations. This paves the way for states to pursue a new approach to foreign policies different from traditional and existing ones. While scholars of international relations have paid more attention on how domestic public influences state interests and policy, the role of domestic public abroad has not been comprehended nor focused. Members of public are poorly informed relative to leaders; they lack knowledge regarding the reasons for a given policy and the relationship between the policy and potential consequences. This is most evident in international affairs,

\footnotetext{
${ }^{5}$ Public diplomacy is perceived as the aggregate of diplomatic efforts in political ideals, public and international policies, and cultural attractiveness. In this way, cultural diplomacy is viewed as a subset of public diplomacy.
} 
where issues are less salient and public is exposed to very little debate and information. Because individuals also have negligible influence on foreign policy, each has little incentive to gather and analyze information. For instance, in the context of coercive intervention on the part of another state, public lacks policy information in two related ways. First, they do not know if the policy serves collective interests or whether it reflects selfish interests with potentially undesirable consequences. Second, they do not know if the proposed policy is a reasonable means to achieve the stated goals (Thompson, 2006: p. 11). Thus, state needs make public of other states to know about its own intension as well informing the public of its own.

World Value Change. Along with increased interdependence and globalization, Inglehart and Welzel (2006) argue that socioeconomic development brings major changes in society, culture, and politics by transforming people's basic values and beliefs. Although socioeconomic development tends to bring predictable changes in people's worldviews, cultural traditions-such as whether a society has been historically shaped by Protestantism, Confucianism, or Communism-continue to show a lasting imprint on a society's worldview. History matters and a society's prevailing value orientations reflect the influence of tradition. Further, modernization is not linear. It does not move indefinitely in the same direction but reaches inflection points at which the prevailing direction of changes. Thus, modernization goes through different phases, each of which brings distinctive changes in people's worldviews. In addition, the inherently emancipative nature of self-expression values makes democracy increasingly likely to emerge. Modernization brings cultural changes that lead to the emergence and flourishing of democratic institutions. The growth of human autonomy is the theme underlying the processes of modernization, rising self-expression values, and democratization. To conclude, socioeconomic development brings increasingly favorable existential conditions and diminishes external constraints on intrinsic human choice. Favorable existential conditions contribute to emerging self-expression values that give individual liberty priority over collective discipline, human diversity over group conformity, and civic autonomy over state authority (Inglehart \& Welzel, 2006). In short, the norms of citizen engagement and transparency, among others, are seen as universal values.

\section{The Korean Wave: Past and Present}

The Korean Wave is generally understood in terms of the recent increase in the popularity of Korean cultural products such as television dramas, movies, popular music (K-pop) and dance (B-boys), video games as well to a lesser extent toward Korean fashion, food, tourism and language. This sudden interest has not gone unnoticed by various media sources, both in Korea and abroad. In the 1990, the Korean Wave started with TV dramas. ${ }^{6}$ For the first time, "Winter Sonata" became popular in Japan and spread to China, Taiwan, and Hong Kong. In the 2000's, the Korean Wave has spread to the world through Internet and social media. TV drama was the first of the Korean Wave, followed by young idol groups (K-pop), movies and various cultural elements.

Korean TV dramas (or mini-series) have been an instrumental component of Korean Wave. The drama Dae Jang Geum

${ }^{6}$ Along with the popular idol group H.O.T.'s who held its first concert in Beijing. provided an opportunity for Korean dramas, which had garnered popularity in China, Japan, and Southeast Asia. Dae Jang Geum, also known as Jewel in the Palace, is based on a real historical figure and takes place against the backdrop of $16^{\text {th }}$ century Chosen Korea. The story portrayed the ups and downs of an orphaned girl who becomes the king's chief physician. The beautiful clothing of the Chosen royal court, the restorations of Chosen architecture, and the colorful palace cuisine sparked global interest in Korean traditional culture. The information on Korean traditional medicine satisfied global trend toward a healthy living (The Korean Wave, 2011: p. 27). After the drama was first aired in Taiwan in 2004, it enjoyed high ratings in Hong Kong and China, touching off a Dae Jang Geum fever in the Chinese-speaking world. The drama has so far been aired in dozens of countries, including China, Vietnam, India, Turkey, Israel, Nigeria, Romania, Hungary, Bosnia, Russia, Sweden, Colombia, Peru, Canada, the United States, Australia, and New Zealand (The Korean Wave, 2011: pp. 28-29).

Korean dramas are popular for various reasons in different countries. Americans find Korean dramas relaxing and cheerful and Europeans find the plots uncomplicated and romantic. Asians, meanwhile, discover lifestyles and trends they wish to emulate. The Middle East finds it the subtle repression of emotions and intense romantic passion without overt sexuality. Muslim countries find the dramas "safe". Saudi Arabia's monarchical government broadcasted Dae Jang Geum and Jumong which portrays Korea's hero-themed drama for emphasizing support and loyalty to the government. While Asians enjoy the common tradition and "against all odd" themes in Korean historical epic dramas, Western audiences like the refreshing humor, fanciful plots, and sincerity such as "My Lovely Kim Sam-soon" and "Boys over Flowers". Unlike Latin American soap operas featuring sexual and sensational topics and scenes, "My Lovely Kim Sam-soon" including romanticism and modern Cinderella storylines was aired on major television networks in Peru in its prime time nine o'clock slot instead of the news (The Korean Wave, 2011).

The Korean Wave is not limited to TV dramas. The new Korean Wave is primarily led by famous Korean girl idol bands such as Girls' generation, Kara and Wonder Girls’. The Korean Wave in the familiar Confucian-based values appeals to Asians. Hong Kong based channel "V" began to feature Korean Pop music videos in the late 1990s (The Korean Wave, 2011: p. 30). The success of H.O.T, Shinwha, NRG, and the girl band Baby Vox in Hong Kong, Taiwan and China emerged as the next epicenter for pop culture. Female singer Boa started her career in Japan and hit the number one position 7 times in the Oricon Weekly Album as she became the first female Korean vocalist to succeed in Japan. One of the most successful boy groups Dong Bang Shinki became the first ever foreign artists top the Oricon weekly single chart nine times and setting a record for the highest ever sales on the first week of release (The Korean Wave, 2011: p. 32). According to the Japanese current events weekly AERA, Korean groups dominated the Japanese music market as the "Korean invasion" and compared K-pop with the British group the Beatles who dominated the American music market in the 1960s (The Korean Wave, 2011: p. 37).

The New-Korean Wave is spear-headed by the spread of the K-Pop. A rapid growth of social network services such as YouTube, Facebook, and Twitter has made it possible to expand the Korean Wave beyond Asia to Europe. Videos of Girl's Generation, provided on SM Entertainment's YouTube channel 
are one of the most widely downloaded videos world-wide. One of those videos, "Gee", has been watched 42 million times by viewers from all over the world, including Thailand, the United States, Japan, and Europe (The Korean Wave, 2011: p. 47). A live YouTube broadcast of a new album by the project team “GD \& TOP” was watched simultaneously by 390,000 people worldwide. In the digital age, when the world is connected via the internet, the effort and cost required to promote Korean culture has dropped dramatically. While the Korean group the Wonder Girls broke onto the Billboard's Top 100 a year earlier only after spending a year performing in the United States, Big Bang's fourth mini album "Tonight" reached No. 6 on the United States' iTunes store, and the music video of its title track was watched one million times within two days of being released on YouTube (The Korean Wave, 2011: pp. 48-49). Furthermore, Billboard.com created “21 Under 21: Music's Hottest Minors 2011” in 2011, and Four Minutes Hyuna ranked $17^{\text {th }}$ overall. The Billboard dot com. introduced Hyuna as one of the key faces of the global K-pop movement. Music video of Hyuna's "Bubble Pop", provided on You Tube channel, had been watched 160 million times as of September, 2011 including the United States, England, France, and Australia. At Paris Conference, SM Entertainment founder and producer Lee, Soo-Man described his company's strategy as “culture technology” and noted that “...unlike information technology, culture technology is more subtle and complicated, as it primarily works with invisible assets and enigmatic human resources and their growth potential...The final state of Hallyu would be sharing and returning added value through localization” (The Korean Wave, 2011: p. 70).

Finally, Kim and Kim (2011, p. 32) conclude that “...Korean media products and their impact are now popular in many Asian countries. Beyond Asia, the Korean cultural wave is extending its reach throughout the world. Although the themes and influences of the Korean Wave are usually accepted in with most countries...Hallyu is certainly an outstanding global media and pop culture phenomenon and has contributed to the globalization of the media market and the diversification of global media studies".

\section{The Korean Wave in Cultural and Historical Perspective}

The basic foundation of the Korean Wave originates from Korean's cultural characteristics that have a strong affinity for music and dance. From the earliest days of Korean history, Korean people have had a love for music and dance. Whether working in the field or celebrating a fall harvest, Koreans people sang and danced to their traditional tunes. Famed Movie Director Lee Jang Ho (2011) affirms that "When I think about the Korean Wave, I realize that we are aware that Korean people are good at music and dance.” Korean folk music includes traditional songs that are orally transmitted over generations. It does not require any special talent or skill, to the contrary anyone can sing individually or as a part of group. In this way, Korean folk music expresses the Korean lifestyle in a simple and honest way that many have enjoyed and cherished for the centuries.

There are three ways to sing Korean fork songs: lead and follow, conversational, and solo. ${ }^{7}$ Lead and follow method is

\footnotetext{
${ }^{7}$ In addition, there are catch song, in which the next singer would catch up to the previous singer, and the hook song in which a succeeding singer would line up to the initiating singer.
}

where one singer would lead a song and the others would follow leader's singing in a choral manner. Current songs of Korean idol groups (or K-pop) are very similar to this traditional method of lead and follow in which a leader of a K-pop group would initiate and start the song and the other group members would follow the leader in harmonious fashion. Another interesting characteristic of Korean traditional music is that it is not, unlike composer oriented Western music, rather Korean folk music is more singer oriented toward he/she can improvise and change the tonal and harmonic delivery. This provides for the Korean people to individually express their musical talents through song and dance. For instance, "Nanta" which is currently performed in various venues in the US is a modern version "Nongak", traditional music performed by farmers.

Samulnori is a type of traditional percussion music. The word samul means "four objects" and nori means "play". It is one of the oldest traditional ceremonial musical patterns which reflect group consciousness of an agricultural community, shamanism, Buddhism and folk entertainment. Thus, there is a strong spiritual energy among farmers. According Lee BaeYoung, the Chief of the Presidential Council on Nation Brand, the Korean Wave has the DNA of traditional culture. Young idol group's role sharing is inheritance of that of agricultural community (Korea Herald, 2011: p. 1). As noted by Cai (2011: p. 1), "The Korean wave is the combination of Confucianism and Western industrial culture. Korean pop culture has borrowed the best of Western popular culture and recreated it according to Korean tastes".

Although Korean history stretches back some 5000 years, Korea has gone through the vortex of world history in the $20^{\text {th }}$ century. The nation had suffered the ills of Japanese colonialism for over 35 years in which Japan tried to Japanese Koreans. The end of colonialism was quickly followed by the Korean War, which destroyed much of the nation's economic and social infrastructure. Korea had to start from scratch in almost everything. Economically Korea embarked on efforts to catch up to so called the developed countries. Culture was no exception to this. Korea has long been acquainted with to imports and been open-minded about foreign cultural products. Ancient Koreans absorbed Buddhism, Confucian teachings and Chinese writings and traditions (The Korean Wave, 2011: p. 17).

More recently, Korea began to absorb American style of living and education, European philosophy, and Japanese modernity. During two wars - one at home and another in Vietnam-soldiers of allied forces brought popular and modern culture in from the United States and other countries. Koreans were hooked to the flood of imported music-American folk, lush ballads, rock, French chansons, Italian canzone; Latin and Cuban music, and Japanese enka-and local singers eagerly mimicked the tunes and styles to ride on the explosive popularity of foreign adult contemporary music in Korea. A lineage of American folk, balladry, R\&B, British rock, and Japanese group "wannabes” sprouted. By the 1980s, when South Koreans were able to afford leisure and entertainment after decades of nonstop industrialization at a galloping pace, more American and European pop culture streamed in.

With the democratization movement that began in the 1980s, regulations on the importation of foreign culture were relaxed. It became trendy to hear American and European pop songs on the radio, American dramas on TV, and Hollywood and Hong Kong films in the theaters. Starting in the mid-1990s, however, things began to change. From the radio, which used to play 
mostly foreign pop songs, Korean pop music flowed all day long, its genres diverse and its quality greatly improved. Record shops were full of sophisticatedly designed albums by Korean artists. Foreign albums, which just 10 years earlier would have been given pride of place, were banished to a corner. The music industry was pumping out big-time local artists. In less than a decade, Korean pop recouped its home turf. On countless cable TV channels, Korean dramas were playing 24 hours a day, and on the weekends the theaters were full of people who had come to see Korean films. Films were drawing audiences of 6 million or more for the first time in Korean cinematic history; the records kept being broken until 2006, when another Korean film recorded an amazing 13 million viewers, equivalent to almost 30 percent of the nation's population at the time. Korea had become one of only a handful of nations that consume more locally produced cultural content than foreign content. And Koreans were not the only ones who began to enjoy Korean pop culture (The Korean Wave, 2011: pp. 17-20).

After the Korean War, Koreans were embarked on a non-stop nation building project to reestablish the political, economic and social pillars of the country. The casting off of the vestiges of Japanese ways coincided with a need to invent new and effective traditions in what Hobsbawm (1983) calls the invention of tradition after rapid transformation. The 1960s to the 1980s laid the foundation for the creation of such inventions, cultural reconstruction, identity development and the participation in the project of modernity (Giddens, 1991). By the 1990s, South Korea had moved beyond what Ingelhart (1999) called the tendency to "emphasize economic growth at any price". Though still thirsting for development and global involvement, two events took place which vastly changed the landscape for South Korea and the future possibility for the Korean Wave: the 1988 allowance of Hollywood to distribute movies directly to theaters, and the 1997 Asian Financial Crisis.

1988 was a big year for South Korea. The Olympics Games were hosted in Seoul, South Korea, making a small Northeast Asian country the sudden center of attention-something South Korea had wanted, but had hardly felt possible since the 1950s. The Games brought brand recognition, forged international partnerships and bolstered the national image, all of which stoked the fire of Korea's slow-growth nationalistic pride. Yet, in the same year the Korean government allowed Hollywood to distribute films directly to Korean theaters, which crushed domestic film popularity and by 1994 foreign visual content enjoyed over $80 \%$ of the market share (Yi, 1994). This was followed by a flood of American products that furthered damaged the Korean culture and industry. There was a growing concern, particularly in the government, that amid development and modernization that Korean-ness and national culture would disappear. How could this occur in a country that has hosted the Olympics? Subsequently, in 1994 a report appeared from the Presidential Advisory Board on Science and Technology discussing how the economy could benefit from the culture industry based on the premise that if Hollywood movie like Jurassic Park could earn as much as selling 1.5 million Hyundai cars, then why shouldn't Koreans try to benefit in such a way (Shim 2006)? The report lead to the establishment of the Culture Industry Bureau, which in 1995 quickly initiated the Motion Picture Promotion Law that forced a quota for Korean film representation in theaters. The government actively and optimistically promoted the fledgling media industry by even going so far as to require financial investment by the large family corpo- rate conglomerates of Korea (the chaebol), like Hyundai, Samsung, and LG (Jin, 2006). Soon domestic production and consumption of Korean cultural products began to establish their roots. Korean companies could enjoy the profit, and Koreans consumers could take pride and participate in their culture in new and different ways.

Just when things were looking up, it was uncovered that that South Korea had accumulated massive foreign debt due largely to the reciprocal relationship between the government and the Chaebol and the latter attempted risky and extensive expansion, leaving the banking industry with numerous non-performing loans which led to the IMF crisis of 1997. Numerous businesses collapsed. Korea's credit rating tanked. And numerous corporate fire sales occurred. When the smoke cleared, South Korea was left injured, but endowed with a cultural legacy of such setbacks, the momentum of the country was hardly slowed. While efforts were made to repair the financial sector, it became increasingly obvious that creating capital was important, thus more money flowed from the Chaebol into their media sectors producing cultural products. The result was the increase in both investment and consumption of Korean cultural products in East Asia over the next few years, which soon expanded to Central and South Asia and eventually to Europe and the Americas.

Hong Quinbo, editor of Dandai stated that “The Korean TV series What is Love had been a huge success in China. The Chinese audience had mostly watched TV soaps from Europe, America, Hong Kong, and Taiwan. After What is Love, the Chinese audience fell for Korean dramas as if they had discovered a whole new world. In 1998, Chinese teenagers colored their hair after the Korean idol group H.O.T. In 1999, a shopping center selling Korean products opened in downtown Beijing. By 2003, Hyundai Motor Beijing was turning out cars and soon becoming as big as American and European brands in China” (The Korean Wave, 2011: p. 21). In this vein, Lee (2011) affirms that "Korea is very small but has made dynamic progress unlike China and Japan. In the new era, the world will focus on culture and Korea has already emerged as a leader. The Twenty-first century is called the 'cultural century', and Korea has a unique and outstanding culture. I positively feel that it could lead the world". Yet, such views do not help easily substantiate the concept or the potential impact of the Korean Wave. It is first necessary to identify exactly what the Korean Wave has been and how it should be defined and in order to ascertain its impact on cultural diplomacy and policy making.

\section{Characteristics of the Korean Wave}

The influx of Korean Wave throughout the world has produced various reactions and impacts. Our observations lead to the following general conclusion regarding the characteristics of the Korean Wave. First, the Korean Wave is not a true 'Korean' wave, rather it is a hybrid of the traditional Korean cultures and western cultures, particularly American. ${ }^{8}$ As pointed out by Shim (2006) cultural hybridization has occurred as local cultural agents and actors interact and negotiate with global forms, using them as resources through which Koreans con-

\footnotetext{
${ }^{8}$ One particularly crucial point about the spread of the Korean Wave is that thanks to digital technology, local cultures can now travel even to remote corners of the world. New media platforms like the Internet and satellite TV have proved vital in spreading Korean culture in markets such as the Middle East, Europe, and beyond. Inter-Asian cultural affinity has also played an important role in the proliferation of Korean culture overseas.
} 
struct their own cultural spaces. In other words, the Korean Wave can be more correctly described as the Korean-hybrid wave. Korean pop culture seduces audiences by combining the enticing images of Westernized modernity with just the right amount of Asian sentimentality. This fusion is at the base of the Korean Wave. Korea took advanced foreign cultures, grafted them onto its own, and produced an advanced culture all its own (The Korean Wave, 2011). You (2006: p. 4) claims that "This, in fact, is the very strength of Korean culture. Having accommodated foreign culture for a long period of time, we have acquired great historical experience of refining imported culture into our own.” Furthermore, Korean scholars credit cultural hybridity with simultaneously promoting globalization and localization of Korean pop culture in both the global and local markets. Since the 1990s, Korean culture has become increasingly globalized (The Korean Wave, 2011).

Second, the spread of the Korean Wave has produced different impacts at the cross-national level, which confirms Florida's view that the world is not flat. Simply put, the effects of cultural fusion are, in the case of the Korean Wave, different across societies and regions. For instance, according to Huang (2011) the Taiwanese appropriation of Japanese and Korean cultures has also created and promoted a hybrid form of culture and consumption, but it did not produce cultural homogenization or cultural autonomy. In Malaysia, the Korean Wave has contributed to enhancing favorable images of Korea, increasing Malaysians' interest in Korea's society and culture, such as language and living (Cho, 2010). As noted by Cai (2011: p. 1), "After the establishment of diplomatic relations between China and Korea in 1992, the relationship between the two countries developed quickly. The two countries share common ground on some important regional issues, such as the North Korean nuclear crisis. They base this diplomatic consensus on their own interests. Because they share the common experience of Japanese invasion, they remain wary of Japan. In addition, Korea is gradually distancing itself from the United States and is increasingly moving close to China, which makes Chinese people more comfortable with Korean culture”.

Third, there have been significant "anti-Korean Wave" movements and slogans in Japan, China, and Taiwan, indicating both the success of the Korean wave and an uneasiness of non-reciprocal cross-cultural exchanges (Lee, 2009). Cai (2011: p. 2) reports that "China's State Administration for Radio Film and Television also said in December 2005 that China had been too generous with the import of Korean TV dramas and called for a stricter screening process. It also said China should limit airtime for Korean dramas to 50 percent. Soon here after, China Central Television said it would gradually reduce the amount of time allotted to soap operas from Korea. Beijing TV said it was pondering a similar move and could start showing more Hong Kong and Taiwan-made soap operas”.

\section{Conclusion}

Now to the question, "Does the Korean Wave affect the political position and diplomatic leverage of Korea in any meaningful way?" We tentatively conclude that the Korean Wave has a positive impact and potential that would promote Korea's cultural diplomacy as a part of soft power approach as argued by Nye along the line of Inglehart's argument of world value change and Keohane and Nye's multiple channels. For instance, Sung (2010) notes that the negative impression of South Korea by Taiwan after the break-up of diplomatic relations (in 1992) has been transformed into a positive image of a nation with confidence and strong nationalism - the Korean Wave provided an opportunity for Taiwan and Korea to build positive relationship and has provided Taiwanese with a new image of South Korea. Moreover, the Korean Wave has promoted increasing cross-cultural ties. Cho (2010) argues that the Korean Wave brought changes to Malaysians' ways of thinking and living and also brought economic changes to Malaysian society by influencing Malaysians to prefer Korean food over Malaysian food and to purchase South Korean goods. Thus, "Malaysia will need Korean experts and Korea will need Malaysian experts to maintain and develop close bilateral relations in the future (Cho, 2010: p. 13)”. Therefore, the Korean Wave can and has served as the cultural resources which would promote cultural and public diplomacy and preferences changes.

The Korean Wave provides a meaningful opportunity for Korean government to take advantage of newly emerging cultural and public diplomacy to promote Korean cultural advantages in globalizing world. Accordingly, Lee (2009: p. 123) positively affirms that “...the Korean wave can contribute to its soft power by providing opportunities for the manipulation of Korea's images, extending a network effect of Korean popular culture, and also producing internationally influential heroes and celebrities”. Figure 1 provides a systemic view of Korean government's effort to promote its cultural diplomacy, headed by the Ministry of Foreign Affairs and Trade and the Presidential Council on Nation Branding.

As noted by Lee (2009) although the Korean Wave can still be creatively mobilized and utilized to achieve many political and economic goals, too deliberate attempt to use cultural assets for political and economic purposes will provoke backlashes as in the case of anti-Korean Wave movements and slogans. Likewise, Lee (2011) adds that "The Korean Government should not take a forefront role in the promotion of its Korean Wave. I wish the authority make young entertainers develop and expand their stage. If the state support or lead, it can cause serious problems. Like a free market economy, let the culture spread itself naturally. The state has not to take the main character in the stage of entertainment business.” Furthermore, culture technology is more subtle and complicated, as it primarily works with invisible assets and enigmatic human resources and their potential growth potential (The Korean Wave, 2011: p. 70).

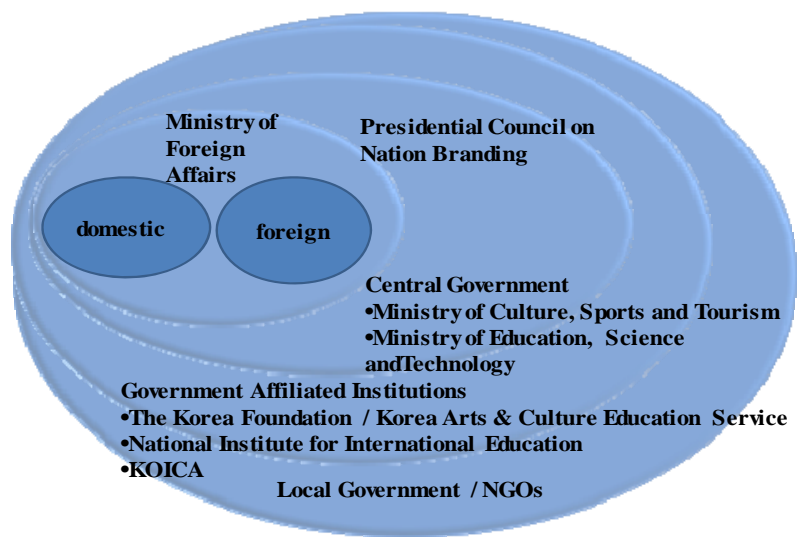

Figure 1.

Organizational chart of Korea’s cultural diplomacy. ${ }^{9}$

${ }^{9}$ This diagram is from Cultural Diplomacy Manual (2011) Ministry of Foreign Affairs and Trade, p. 26. 
We suggest that the cultural diplomacy initiative should be designed to help educate, enhance, and sustain the relationships between countries and cultures. ${ }^{10}$ The ultimate goal of the initiative is to help enable relationships between neighboring countries based on dialogue, understanding and trust. We suggest a cultural diplomacy initiative that assists in correcting mis-information that might be present and supplements partial information that might already be present. In order to maintain as much neutrality as possible, and to achieve the maximum amount of success, we suggest that the main agent or organizer of the proposed cultural diplomacy be a non-governmental, non-profit, and non-partisan organization. Furthermore, we suggest that the vehicle of the proposed cultural diplomacy initiative would be to create a sustainable network of young professionals and students within and across the region. Finally, we suggest that the target audience be as broad and inter-disciplinary as possible. For instance, the student exchange programs should include as many academic fields as possible and the young leaders network should remain inter-disciplinary and international in nature. Thus, we would recommend a more prudent and pluralistic approach in which the Korean government plays in facilitating the Korean Wave that are less explicit or more implicit, in a balanced way, such as more support for corporate sponsorships, private entrepreneurships and NGO engagements.

\section{REFERENCES}

Baker, A. (2000). Globalization and the British "residual state". In R. Stubbs, \& G. R. D. Underhill (Eds.), Political economy and the changing global order (pp. 366-367). Toronto, Ontario: Oxford University Press.

Brawley, M. (2003). The politics of globalization. Peterborough, Ontario: Broadview Press.

Cai, J. (2011). The first taste of Korean wave in China. URL (last checked 15 October 2011). journeyeast.tripod.com

Castells, M. (2004). The network society: A cross-cultural perspective. Northampton, ME: Edward Elgar Publishing, Inc.

Cho, C. (2010). Korean wave in Malaysia and changes of the KoreanMalaysia relations. Malaysian Journal of Media Studies, 12, 1-14.

Chua, B. H., \& Iwabuchi, K. (Eds.) (2008). East Asian pop culture: Analysing the Korean wave. Hong Kong: Hong Kong University Press.

Cultural Diplomacy Manual (2011). Ministry of foreign affairs and trade. Seoul.

Feiock, R., M. J. Moon, \& H. J. Park (2008). Is the world flat or spiky? Rethinking governance implications of globalization for economic development. Public Administration Review, 68, 1.19.

Florida, R. (2005). The world is spiky. The Atlantic Monthly, October.

Freidman, T. (2005). The world is flat: A brief history of the twenty-first century. Farrar, Straus and Giroux.

Giddens, A. (1991). Modernity and self-identity. Oxford: Polity.

Hobsbawm, E. (1983). Introduction: Inventing Traditions. In E. Hobsbawm, \& T. Roger (Eds.), The Invention of Tradition (pp. 1-14). Cambridge: Cambridge University Press.

Huang, S. (2011). Nation-Branding and transnational consumption: Japan-mania and the Korean wave in Taiwan. Media, Culture \& Society, 33, 3-18. doi:10.1177/0163443710379670

Inglehart, R. (1999). Global trends: A glimpse ahead: Globalization and postmodern values. The Washington Quarterly, 23, 215-228. doi:10.1162/016366000560665

Inglehart, R., \& Welzel, C. (2006). Modernization, cultural change, and democracy. New York, NY.: Cambridge University Press.

Jin, D. Y. (2006). Cultural politics in Korea's contemporary films under national globalization. Media, Culture \& Society, 28, 5-23. doi:10.1177/0163443706059274

Keohane, R., \& Nye, J. (2001). Power and interdependence (3rd ed.). New York: Longman.

Kim, D., \& Kim S. (2011). Hallyu from its origin to present: A historical overview. In D. Kim, \& M. Kim (Eds.), Hallyu: Influence of Korean popular culture in Asia and beyond (pp. 13-34). Seoul: Seoul National University Press.

Kim, J., \& Ni, S. (2011). The Nexus between Hallyu and soft power: Cultural public diplomacy in the era of sociological globalism. In D. Kim, \& M. Kim (Eds.), Hallyu: Influence of Korean popular culture in Asia and beyond (pp. 132-154). Seoul: Seoul National University Press.

Korea Herald (2011). Korea works to sell its "brand” worldwide. URL (last checked 21 November 2011).

http://www.koreaherald.com/lifestyle/Detail.jsp?newsMLId=201111 17000559

Lee, G. (2009). A soft power approach to the "Korean wave". The Review of Korean Studies, 12, 123-137.

Lee, J. (2011). Personal interview. Seoul. 18 September.

Nye, J. (2004). Soft power: The means to success in world politics. New York: Public Affairs.

Shim, D. (2006). Hybridity and the rise of Korean popular culture in Asia. Media, Culture \& Society, 28, 25-44. doi:10.1177/0163443706059278

Sung, S. Y. (2010). Constructing a new image. Hallyu in Taiwan. European Journal of East Asian Studies, 9, 25-45. doi:10.1163/156805810X517652

The Korean Wave: A New Pop Culture Phenomenon (2011). Contemporary Korea No. 1. Korean Culture and Information Service, Seoul.

Thompson, A. (2006). Coercion through IOs: The security council and the logic of information transmission. International Organization, 60, $1-34$.

Yi, G. (1994). Foreign visual content possesses $87 \%$ of Korean market. Joongang Ilbo, 45, 6 October.

You, H. (2006). The origin and future of "Hallyu". Korea Focus. URL (last checked 27 October 2011).

http://www.koreafocus.or.kr/design1/Essays/view.asp?volume_id=48 \&content_id=101408\&category $=\mathrm{G}$

\footnotetext{
${ }^{10}$ We have structured our recommendations along the following items: 1. Agenda of the Proposed Cultural Diplomacy Initiatives, 2. Agents or Organizers of the Proposed Cultural Diplomacy Initiatives, 3. Vehicles of Proposed Cultural Diplomacy Initiatives, and 4. Target Audience of the Proposed Cultural Diplomacy Initiatives. These recommendations are based on the Report of Workshop, "East Asian Community Building: Cultural Diplomacy as a Policy Tool of Soft Power," co-organized by Jeju Peace Institute and Friedrich Naumann Foundation for Freedom, Jejudo, Korea, October 6, 2011.
} 